\title{
Ranking Score of Financial Condition and Fear of Bankruptcy to Evaluate Operation's Continuity of Dairy Milk Processing Companies: Evidence from the Republic of Belarus
}

\author{
Stanislava KONTSEVAYA, Sergei CHACHOTKIN, Raisa KOSTINA, Ludmila \\ KHORUZIY \\ Russian State Agrarian University - Moscow Timiryazev Agricultural Academy, Moscow, \\ Russia \\ s.kontsevaya@gmail.com, sergei.chachotkin@mail.ru, \\ \{kostina, hli\}@timacad.ru
}

\begin{abstract}
The article covers issues of bankruptcy detection in the context of dairy milk processing companies of the Republic of Belarus. Republic of Belarus is exporter of milk products i.e. more than $60 \%$ of products are exported abroad. Gross output of milk products is more than 7 thou tons. To keep successful functioning of diary milk processing companies it is important to estimate financial condition of the companies and detect possibility of bankruptcy in time. The article contains 11 models of bankruptcy detection, which provide the basis for the new model taking into account specificity of diary milk processing industry. Suggested methodology of ranking score to detect threat of bankruptcy classifies financial coefficients by reliability for specific diary milk processing company. Condition of the company may be evaluated as crisis, pre-crisis, unstable normal or absolute. This study includes examples of calculation for 6 major diary milk processing companies of the Republic of Belarus. These calculations prove the fact that possibility of bankruptcy is unstable every year. Such condition might be caused by many internal and external factors such as sanctions, embargo, restructuration and loss-making company takeover. Practically implemented this methodology should only be included into the notes of accounting reports of the company. It may be helpful for auditors and external users to estimate stability of the company and risk of bankruptcy and take reasonable decision about management of risks.
\end{abstract}

Keywords: Dairy industry, Milk processing, Financial analysis, Accounting.

\section{$1 \quad$ Introduction}

Milk processing industry is a brand identity of the food industry in the Republic of Belarus. It produces milk, butter, cheese, ice cream, tinned milk etc. Milk processing industry is an important part of the food facility of the country. Hence, the financial 
condition of milk processing companies should be done in time in order to estimate financial condition of the company and reveal threat of bankruptcy [15]

According to IAS [8] the concept of accounting report preparation supposes that company's activity is continuous. It is one of the key suggestions in case of preparation of accounting reports of all companies regardless their form of ownership. This concept suggests that steadily developed company continues its activity without temporary or target limits. One of the key reasons of interrupted activity of the company is bankruptcy. If the analysis of financial and operational activity of the company reveals risk of bankruptcy the activity of this company should not be considered continuous. If the company is under bankruptcy and no methods of solvency recovering are helpful it is closed down and its property is sold to liquidate debts [11]. Under growing instability of environment, the company is expected to implement special actions such as internal control and permanent monitoring of external changes of the market in order to avoid bankruptcy of the company.

There are a lot of methodologies of bankruptcy risk estimation and risk management algorithms described in Russian [2, 9, 10, 14], American and European [1, 5, 6, 12] studies. However, their implementation sometimes does not provide real condition and the ways for its correction. Some models include wasteful calculations and their results are not convenient to be read by managers. Hence, they provide implicit information about stability of functioning of the company, so it is insufficient for taking reasonable management decisions.

The article is aimed to estimate financial condition of major diary milk processing companies of the Republic of Belarus and develop advanced methodology of bankruptcy risk detection.

The article involves the following key items:

- Description of modern condition of production, processing and consumption of milk in the Republic of Belarus.

- Suggestion of advanced methodology of bankruptcy risk detection with regard to specificity of diary milk processing industry.

- Estimation of financial condition of 6 major milk processing companies

\section{Materials and Methods}

\subsection{Key Factors of Milk Processing Industry of the Republic of Belarus}

For the last 5 years the Republic of Belarus has been keeping the position among 5 major exporters of milk products in the world. Its share in the total worldwide export of milk is $5 \%$ by the end of 2017. Key importers of Belarusian milk products are EU countries [4].

Agriculture of the Republic of Belarus traditionally specifies in milk production and processing. Relative share of milk in the structure of saleable agricultural products is more than $25 \%$. 
The Republic of Belarus exports more than $60 \%$ of milk products. Over recent years diary milk processing industry has been disbursing government investments in accordance with special support program.

Table 1. Key production and economic factors of diary milk processing industry development in the Republic of Belarus in the period $2010-2017$.

\begin{tabular}{lllll}
\hline Indicator & 2010 & 2014 & 2017 & $\begin{array}{l}2017 \mathrm{in} \mathrm{\%} \\
\text { to } 2010\end{array}$ \\
\hline $\begin{array}{l}\text { Yearly average cow population, } \\
\text { thousands of heads }\end{array}$ & 1,445 & 1,525 & 1,502 & 103.9 \\
$\begin{array}{l}\text { Gross output of milk, thousand tons. } \\
\text { Milk yield per cow, kg. }\end{array}$ & 6,624 & 6,703 & 7,322 & 110.5 \\
$\begin{array}{l}\text { Final disposal price of 1 ton of milk, } \\
\text { thou. RUB }\end{array}$ & 4,630 & 4,508 & 4,943 & 106.8 \\
Profit margin, \% & 12.1 & 4,231 & 5,534 & 648.0 \\
\hline
\end{tabular}

Source: Statistical compilation Agriculture of the Republic of Belarus, own calculations

According to the data from Table 1 cow population has grown on $3.9 \%$, gross output of milk has increased on $10.5 \%$ and capacity of cows - on $6,8 \%$ for the abovementioned period. Final disposal price of milk has 6.5 times increased from 2010 to 2016. Profitability of diary milk processing industry was $28.3 \%$ in 2016 that is higher on $16.2 \%$ by comparison with 2010 .

Analysis of milk and milk products consumption in the Republic of Belarus per capita in $2010-2017$ (Fig. 1)

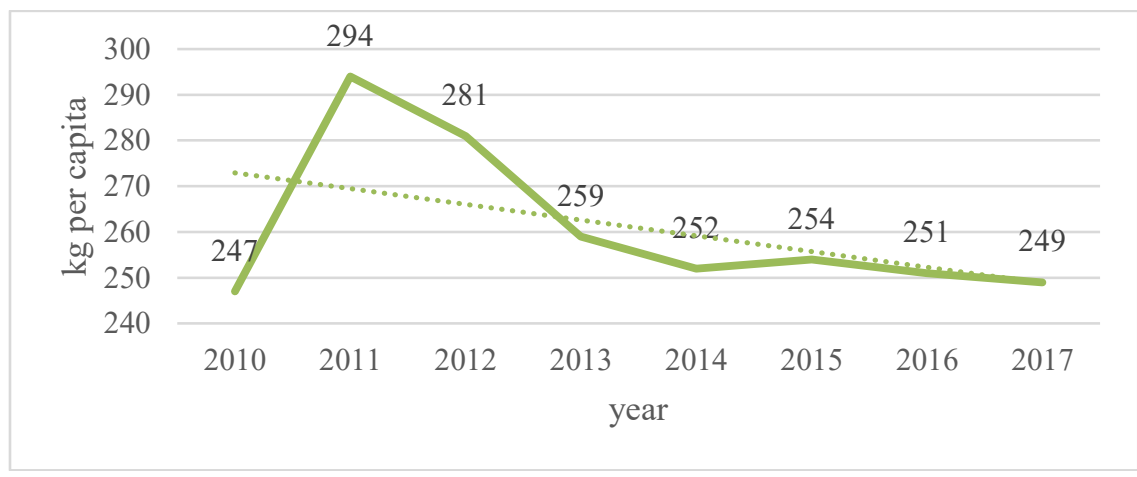

Fig. 1. Consumption of milk and milk products in the Republic of Belarus in 2010-2017, $\mathrm{kg} /$ person [16].

Analysis of Fig. 1 obviously evidences the trend of decreased consumption of milk and milk products per capita. From 2011 to 2017 the consumption decreased on $18.1 \%$ and in 2017 it was $249 \mathrm{~kg}$ per person. This is due to a general decline in household income. It should be noted that the Republic of Belarus keeps 1 position among EU countries in production and consumption of milk and milk products per capita. 


\subsection{Methodology}

This study involves analysis of 6 major milk processing companies in the Republic of Belarus i.e. Babushkina krynka JSC, Savushkin product JSC, Bellakt JSC, Milkavita JSC, Minsk dairy plant number 1 JSC and Lepel JSC. Data for analysis was taken from the database of accounting reports [7]

Analysis of bankruptcy risk made from 11 models in Table 2 proved that the specificity of diary milk processing industry was not taken into account completely. Therefore suggested model was developed in order to take into account specific features of agricultural milk processing companies. In this model financial coefficients are classified by reliability for milk processing companies, ranking scores of financial condition, mark scores of bankruptcy risk and continuity of operation.

Table 2. Summary of bankruptcy risk estimation of Babushkina krynka, JSC 2013-2017 [3].

\begin{tabular}{lccc}
\hline Indicator & 2013 & 2015 & 2017 \\
\hline Two-factor model by Altman & Less $50 \%$ & Less $50 \%$ & Less $50 \%$ \\
$\begin{array}{l}\text { Modified five-factor model by Altman } \\
\text { R.Taffler and G.Tishow model }\end{array}$ & $50 \%$ & High & High \\
$\begin{array}{l}\text { Model by Springate } \\
\text { Four-factor model IGEA }\end{array}$ & Low & Middle & Low \\
$\begin{array}{l}\text { Model by Lis } \\
\text { Model by O.P. Zaytseva }\end{array}$ & Till to $10 \%$ & High & High \\
$\begin{array}{l}\text { Model by R.S.Sayfullin and G.G.Kadykova for } \% \\
\text { financial condition estimation }\end{array}$ & High & High & High \\
$\begin{array}{l}\text { Model by G.V.Savitskaya for production } \\
\text { companies }\end{array}$ & Unstable & High & High \\
$\begin{array}{l}\text { Model by G.V.Savitskaya for agricultural } \\
\text { companies }\end{array}$ & Low & Unstable \\
$\begin{array}{l}\text { Model by Biver (Biver's coefficient, standard } \\
\text { value not less than } 0,17 \text { ) }\end{array}$ & Very Low & Very Low & Very High \\
\hline
\end{tabular}

Based upon methodologies from Table 2 suggested methodology was specified with regard to estimation of financial condition of milk processing agricultural companies. The criteria for financial condition estimation were calculated on the basis of practical functioning of Russian milk processing agricultural companies.

Analysis of financial condition of milk processing companies revealed common factors of liquidity and financial sustainability and specific factors of monetary flows.

It should be noted that Russian methodologies [9, 14] of bankruptcy risk estimation are focused on functioning with internal funds while American methodologies [1] are based upon loan capital. Suggested methodology takes into account both internal and loan funds, monetary flows allowing estimating capability of the company to pay debts and available cash assets proving solvency of the company.

Classification of liquidity and financial sustainability coefficients and specific factors of monetary flows is specialized for milk processing agricultural companies. Rated from absolute to crisis financial condition is defined by 13 coefficients. Common 
liquidity factors and financial sustainability factors (coefficients) were taken as factors of financial condition and their values are calculated. These factors are:

1) Absolute liquidity (K1). Standard value of this coefficient should be equal or more than 0.2 . The most appropriate range of its values for milk processing companies is $0.15-0.2$ with regard to specificity of this industry.

2) Intermediate (fast) liquidity (K2). Standard value of this coefficient is 0.7 . It should be noted that this value is not sufficient sometimes as major part of liquid assets is presented by accounts receivable in some companies. It is difficult to be collected in time. In case of milk processing companies, desirable value of this coefficient is 1 or more.

3) Current liquidity (K3). According to the legislation of the Republic of Belarus standard value of this coefficient for milk processing companies should be taken $\geq 1.3$.

4) Total liquidity (K4). Recommended value of this coefficient for milk processing companies belongs to range from 1 to 2 . Lower value of this coefficient means that current assets are insufficient for payment of small debts.

5) Provision with internal funds (K5). According to the legislation of the Republic of Belarus standard value of this coefficient for milk processing companies should be more than 0.2. In researches by G.V. Savitskaya [13] standard value of this coefficient is taken from 0.2 to 0.5 . The closer value to 0.5 the more resilient the company is.

6) Covering of current assets with internal funds (K6). Standard value of this coefficient is more than 0.1 for milk processing companies;

7) Autonomies (financial independency) (K7). According to the legislation of the Republic of Belarus standard value of this coefficient should not be less than $0.4-0.6$ in order to consider the company financially stable.

8) Capitalization (K8). According to the legislation of the Republic of Belarus standard value of this coefficient should not be more than 0.1 .

9) Financial stability (K9). Standard value of this coefficient should be equal or more than 0.75 . If the value of this coefficient is in the range from 0.8 to 0.9 the company moves in positive trend and its financial condition is stable.

10) In-house solvency (K10). Standard value of in-house solvency coefficient should not be less than 0.1 at international level. It is individual value for each company depending on production and financial operations of the company.

Specific factors of monetary flows (coefficients):

11) Cash cover of debts (K11). Standard value of this coefficient should be 0.17 0.45 for milk processing company;

12) Self-financing of investment activity (K12). Standard value of this coefficient should be more than 1 . If it is less than 1 the company should use loans for investment activity.

13) Self-financing of payments within financial activity (K13). Standard value of this coefficient should be more than 1 otherwise there are corporate risks for milk processing agricultural companies.

Suggested methodology of bankruptcy risk estimation is based upon summarized data about national and foreign methodologies. Milk processing agricultural companies were classified by the extent of reliability. Each effective value of the coefficient was characterized by definite mark score qualifying the company to some class ( 5 classes 
correspond to 5 financial conditions: absolute, normal, unstable, pre-crisis and crisis). Achieved criterion is provided with the class: absolute financial condition -10 scores, normal financial condition - 8 scores, unstable financial condition -6 scores, pre-crisis financial condition - 4 scores, crisis financial condition - 2 scores. Distribution of financial coefficients by reliability classes for milk processing company is provided in Table 3.

Table 3. Distribution of financial coefficients by reliability classes for milk processing agricultural company.

\begin{tabular}{lccccc}
\hline Indicator & Absolute & Normal & Unstable & Pre-crisis & Crisis \\
\hline K1 & $\geq 0.2$ & $0.2-0.15$ & $0.15-0.10$ & $0.10-0.05$ & $\leq 0.05$ \\
K2 & $\geq 1$ & $0.7-1$ & $0.7-0.6$ & $0.6-0.4$ & $\leq 0.4$ \\
K3 & $\geq 1.5$ & $1.5-1.3$ & $1.3-1.0$ & $1.0-0.5$ & $\leq 0.5$ \\
K4 & 2 & $1-2$ & $0.9-1.0$ & $0.6-0.9$ & $\leq 0.6$ \\
K5 & $>0.5$ & $0.2-0.5$ & $0.1-0.2$ & 0.1 & $<0.1$ \\
K6 & $>0.5$ & $0.3-0.5$ & $0.1-0.3$ & 0.1 & $<0.1$ \\
K7 & $\geq 0.6$ & $0.4-0.6$ & $0.4-0.3$ & $0.3-0.1$ & $<0.1$ \\
K8 & 1 & $1.0-1.5$ & $1.5-1.7$ & $1.7-2.0$ & $>2$ \\
K9 & $0.8-0.9$ & $0.8-0.75$ & $0.75-0.65$ & $0.65-0.50$ & $<0.50$ \\
K10 & $>0.1$ & 0.1 & $0.1-0.08$ & $0.08-0.05$ & $<0.05$ \\
K11 & $>0.45$ & $0.17-0.45$ & $0.17-0.12$ & $0.12-0$ & $<0$ \\
K12 & $\geq 1$ & $0.6-1$ & $0.6-0.4$ & $0.4-0$ & $\leq 0$ \\
K13 & $\geq 1$ & $0.6-1$ & $0.6-0.4$ & $0.4-0$ & $\leq 0$ \\
\hline
\end{tabular}

All scores are summed and the total score presents the ranking of the milk processing agricultural company (Table 4).

Table 4. Ranking of financial condition of milk processing agricultural companies.

\begin{tabular}{lll}
\hline Amount & Rating & Criteria \\
\hline $105-130$ & Absolute & High efficient company, absolute financial stability \\
$79-104$ & Normal & Normal financial stability \\
$53-78$ & Unstable & Unstable financial condition \\
& & $\begin{array}{l}\text { Insolvent and inefficient company, pre-crisis financial } \\
\text { condition }\end{array}$ \\
$0-26$ & Pre-crisis & Bankruptcy \\
\hline
\end{tabular}

\section{Results and Discussion}

Calculation of suggested methodology of bankruptcy risk estimation and disclosure of information about continuity of functioning in comments of accounting (financial) reports and their remarks is provided for Babushkina krynka JSC over the period of 2015-2017 (Tables 5 and 6). Disclosure of information about continuity of functioning is suggested in comments to accounting (financial) reports and remarks about financial 
condition of the company divided into reliability classes are provided in view of the table (Table 6).

Table 5. Score estimation of bankruptcy risk for the agricultural company Babushkina krynka JSC in 2015-2017.

\begin{tabular}{lcccccc}
\hline Indicator & 2015 & Score & 2016 & Score & 2017 & Score \\
\hline K1 & 0.04 & 2 & 0.02 & 2 & 0.02 & 2 \\
K2 & 0.47 & 4 & 0.4 & 2 & 0.49 & 4 \\
K3 & 0.72 & 4 & 0.66 & 4 & 0.78 & 4 \\
K4 & 0.3 & 2 & 0.29 & 2 & 0.37 & 2 \\
K5 & -0.37 & 2 & -0.5 & 2 & -0.28 & 2 \\
K6 & -2.11 & 2 & -2.25 & 2 & -1.27 & 2 \\
K7 & 0.37 & 6 & 0.33 & 6 & 0.29 & 6 \\
K8 & 1.74 & 4 & 2.02 & 2 & 2.45 & 2 \\
K9 & 0.72 & 6 & 0.69 & 6 & 0.60 & 4 \\
K10 & -0.28 & 2 & -0.33 & 2 & -0.22 & 2 \\
K11 & -0.18 & 2 & 0.06 & 4 & 0.06 & 4 \\
K12 & -1.03 & 2 & 0.39 & 4 & 0.66 & 8 \\
K13 & -0.35 & 2 & 0.10 & 4 & 0.06 & 4 \\
Total score & - & 40 & - & 42 & - & 46 \\
\hline Desision & Pre-crisis & & Pre-crisis & & Pre-crisis & \\
\hline
\end{tabular}

Results of calculations of suggested methodology of bankruptcy risk estimation and information about continuity of functioning for some milk processing agricultural companies Babushkina krynka JSC, Savushkin product JSC, Bellakt JSC, Milkavita JSC, Minsk dairy plant number 1 JSC, Lepel JSC in 2015-2017 is provided in Table 6.

Table 6. Score estimation of bankruptcy risk of milk processing agricultural companies in the Republic of Belarus in 2013-2017.

\begin{tabular}{lllllll}
\hline Firm & Score & 2015 & Score & 2016 & Score & 2017 \\
\hline Babushkina krynka & 40 & Pre-crisis & 42 & Pre-crisis & 46 & Pre-crisis \\
Savushkin product & 70 & Unstable & 88 & Normal & 110 & Absolute \\
Bellakt & 66 & Unstable & 48 & Pre-crisis & 110 & Absolute \\
Milkavita & 32 & Pre-crisis & 36 & Pre-crisis & 64 & Unstable \\
Minsk dairy plant 1 & 60 & Unstable & 80 & Normal & 80 & Normal \\
Lepel & 26 & Crisis & - & - & - & - \\
\hline
\end{tabular}

Changes in financial condition of milk processing agricultural companies over considered period are caused by some internal and external factors such as global economic crisis, sanctions [17] and embargo of import of milk products into the Russian Federation. These factors result in decreased benefit and earning capacity of the company making its financial condition worse. Internal factors involve business combination and restructurisation of milk processing companies. Acceding loss- 
making company degrades financial condition of more profitable companies (for instance the company Bellakt in 2015). The topic of further researches might be prediction of bankruptcy risks.

\section{Conclusion}

Milk production industry is one of the most important industries providing high quality of food for population of the country. Moreover, the Republic of Belarus is the major exporter of milk products therefore the estimation of financial condition of the companies is of great importance.

Suggestion of continuous accounting reports of the company provide diagnostic of bankruptcy risk in time.

The article contains critical evaluations of bankruptcy diagnostic models and suggests the model of bankruptcy risk estimation specified for milk processing company.

Each company was classified by definite score. This score is based upon coefficients of financial condition and calculated with regard to specificity of milk processing industry. Condition of the company made by the sum of scores may be evaluated as crisis, pre-crisis, unstable, normal or absolute.

Calculation for 6 major milk processing companies in the Republic of Belarus reveals fluctuate character of bankruptcy threat every year. It is cause by some internal and external reasons such as sanctions, embargo, restructurisation and loss-making company takeover.

This calculation is suggested to be attached to accounting reports. It will help auditors and other users to estimate continuity of functioning of the company and take reasonable decision concerning management of risks.

\section{References}

1. Altman, E. I., Haldeman, R. Narayanan, P.: Zeta analysis: A new model to identify bankruptcy risk of corporations. Journal of Banking \& Finance, Vol. I., pp. 29-54. (1977)

2. Bulava, I. Termination of companies and the bankruptcy of Russian enterprises. Journal Finance, money, investment, 4(44), 11-16(2012)

3. Chachotkin, S.: Improving the financial risk management system (Совершенствование системы управления финансовыми рисками): BGSHA,Gorki (2016).

4. Dairy industry. http://www.uniter.by/upload/Dairy_industry.pdf URL last accessed 2018/10/14

5. Doubek, V., Švasta, J., Blažková, L.: Agricultural trade on the example of milk from the perspective of the multi-criteria analysis, Agricultural Economics, Vol. 58, No. 7, pp. 315323. ISSN 0139-570X (2012)

6. Foltínová, A. Špička, J.: The use of controlling in agricultural enterprises and their competitiveness", Agricultural Economics, Vol. 60, No. 7, pp. 314-322. (2014) ISSN 0139$570 X$. 
7. GIVTS Ministry of Agriculture and Food (ГИВЦ Минсельхозпрода) http://givc.by/services/sbor-obrabotka-analiz-otchetnosti-predpriyatiy-apk/pk-bukhstat/ URL last accessed 2018/10/14

8. International Financial Reporting Standard (IAS) "Presentation of financial statements" (valid on Belarus Republic at 30.12.2016 № 1119/35) http://pravo.by/ URL last accessed 2018/10/14

9. Melnik, M.: Economic analysis in auditing (Экономический анализ в аудите). Revised edition. UNITY Publishers, Moscow (2007)

10. Ovchinnikova, N.N.: Evaluation of the continuity of the organization: problems and their solution. Journal Current issues of economic sciences (Актуальные вопросы экономических наук), 4(2) 139-144 (2009).

11. Rozsa, A.: Financial performance analysis and bankruptcy prediction in hungarian dairy sector. Annals of the University of Oradea: Economic Science, Vol. 23, No. 1, pp. 938-947. (2014) ISSN 1222-569X.

12. Ratinger, T., Bošková, I.: Strategies and effects of milk producers' organizations in the Czech Republic, Agricultural Economics, Vol. 59, No. 3, pp. 113-124. ISSN 0139-570X. (2013)

13. Savitskaya, G.: Economic analysis. 11 edn. Novoe znanie, Moscow (2005)

14. Soldatov, A., Korzhavina, E.: Analysis of financial characteristics of the continuity of the organization. Proceedings of the International Scientific Conference "The strategy of socioeconomic development of society: managerial, legal, economic aspects", pp. 142-145. Timyryazev University, Moscow (2016)

15. Špička, J.: The efficiency improvement of Central European corporate milk processors in 2008 - 2013", Agris on-line Papers in Economics and Informatics, Vol. 7, No. 4, pp. 175188. (2015) ISSN 1804-1930.

16. Statistical compilation Agriculture of the Republic of Belarus. Statistical committee, Minsk (2018)

17. Smutka, L., Spicka, J., Ishchukova, N., Selby, R.: Agrarian import ban and its impact on the Russian and European Union agrarian trade performance", Agricultural Economics, vol. 62, no. 11, pp. 493-506, (2016) ISSN 1805-9295, DOI 10.17221/294/2015-AGRICECON 